\title{
The Challenges of Historically Black Universities in the Post-Apartheid Era: Towards Educational Transformation
}

\author{
Moses Hobe
}

\begin{abstract}
The classic notion of apartheid education was that "Education must train and teach people in accordance with their opportunities in life as well as the spheres in which they live." Therefore this segregated and inferior schooling agenda provided an ideological cornerstone for social segregation, economic exploitation and political oppression and made education serve as an instrument to ensure white domination. As a result, historically black universities were perceived to be at the bottom in terms of teaching as an act of scholarship as well as quality knowledge generation. Though historically black universities in South Africa played a pivotal role in educating and empowering Black students to think critically as well as participate in vocational and economic competence, there is yet a great need to honestly observe and evaluate the current state of affairs in higher education in the post-apartheid era. This paper therefore seeks to identify some of the challenges and opportunities facing (HBUs), Faculty and students as well as propose a workable model for (HBUs) to be competitive in offering quality teaching and learning as well as avoid ineffectiveness among graduates in the changing South Africa
\end{abstract}

Keywords - Apartheid, Education, HBUs, Transformation.

\section{INTRODUCTION}

According to Elias (2002:258) "A knowledge of history certainly helps us understand the past and how the past has shaped the present. It may enable us to understand present challenges and move toward a more helpful future." Leshoro (2008:4) points out that, one of the most far-reaching consequences of apartheid in South Africa has been the damage done to the education system. Steyn et al (2014) quoting Gbadamosi and De Jager (2009) argues that consequently higher education institutions in South Africa went through changes in structuring, funding and student numbers due to government's policy to transform higher education in South Africa, as well as globalization and internationalization. Be it as it may statistics based on the SAHRC report (2014: Viii) confirms that more than 20 years into democracy, South Africa continues to face deeply entrenched inequalities in all spheres of our society, including our public universities.

Despite notable progress made in addressing historical inequalities in public universities patterns of systemic exclusion, marginalization and discrimination still persist. It is with this rapidly changing scenario of South Africa, that a vision of transformation of universities has to be developed (Reddy

Manuscript received October 26, 2017

M. Hobe, Development Studies, University of Venda South Africa.
1992:59). This paper therefore attempt to highlight some of the challenges faced by the historically black universities in the post - apartheid as well as put forward propose methodologies towards educational transformation.

\section{DEFINITION OF CONCEPTS}

\section{A. Apartheid}

(In the Republic of South Africa) a rigid former policy of segregating and economically and politically oppressing the nonwhite population (www.dictionary.com). Hofmeyer and Pillay (1994:246) further adds that apartheid was ideologically underpinned by a Christian nationalist ideology, which, through a narrow and distorted reading of the Bible, attempted to justify racial separation in terms of the 'calling' and 'mission' of Afrikaner self-preservation in an African context.

\section{B. Education}

Du Toit (2007: 10) citing the World Book Encyclopedia (1988:84) which defined education as aiming "at producing intelligent, responsible, well-informed citizens who take an active interest in the world around them. It is designed to transmit a common cultural heritage." Reagan (2005:7) sees the above perspective of education as "dramatically distorting the reality of the African experience." Du Toit adding to the definition of education profoundly says that the term "education" refers to a fully balanced growth of children and adults, comprehending all aspects of human life, in informal as well as formal educational settings.

According to (www.dictionary.com), education is the act of imparting or acquiring general knowledge, developing the powers of reasoning and judgment, and generally of preparing oneself for others intellectually for mature life.

\section{HBUs}

In the South African context HBUs refers to institutions of higher learning established for the sole purpose of catering for students from the majority black population. Reddy (1992:59) asserts that the history of most of these universities were intimately shaped by the anti-apartheid struggle.

\section{Transformation}

Transformation has become one of the most commonly used words in post -1994 South Africa. It signifies the dramatic changes that have taken place in the country's traditional relations of power and privilege, and changes (Esterhuyse 
2000:145).

\section{EDUCATION IN THE POST-APARTHEID SOUTH AFRICA}

De bruijn et al (2001:4) in Steyn (2014:1) records that following 46 years under an apartheid government, South Africa underwent transformation in 1994 to become a democratic state. The South African White Paper (2001:4) further reports that "from then on educational reformers attempted to provide a system of education that builds democracy, human dignity, equality and social justice."

The primary aim of the reforms was to broaden participation in high education so as to reduce the highly stratified and class structure of the country (Fraser and Killen, 2005).

The most relevant question to ask in 2017 is that, where are we now in such a developmental process? In answering this question I think the words of (lodge 1994) in Kunie (2000:161) adds value to this paper, in saying that: "A perusal of the educational situation of South Africa today indicates that the country is mired in a socioeducational crisis of monumental proportions. Black people's expectations of a free and decent education, with reduced class sizes and free textbooks, as promised during 1994 elections, have been frustrated and remain apparently distant dreams." The university system as we have it to some extent still resembles the $19^{\text {th }}$ century European model (Hoppers 2010:43).

I definitely agree that the process of transition is not without its difficulties. But the issue is that despite notable progress made, there is still so many challenges within the HBUs, which if not attended to complete transformation will not be realized.

\section{CHALLENGES OF HISTORICALLY BLACK UNIVERSITIES}

\section{A. Access to Higher Education}

According to (Matos 2000:15) "Access to higher and particularly university education has become a major problem in virtually every African country. The number of students completing secondary education and applying to universities has increased to such an extent that university systems can no longer cope." Tertiary institutions in South Africa also experienced an impressive growth in student numbers and historically white universities experienced a dramatic shift in demographics as well (Steyn 2014: 1).

Despite the desegregation of the South African educational system and the more equitable allocation of resources, traditional black schools are still to a great extent disadvantaged and therefore failing in preparing students sufficiently for tertiary demands (Griffin \& Allen, 2006). The transition from school to university is daunting since they are faced with increasing linguistic demands, more rigorous performance requirements which and diverse cultural environments which may conflict with their personal values and beliefs (Steyn 2014:2)

The secondary education system is in South Africa is so low in quality and as a result high schools are failing to prepare learners adequately hence there is too much underperformance due to this unpreparedness. Because of the influx of learners from high school to universities the HBUs is disadvantaged and the other challenge is that quality is compromised.

\section{B. Infrastructure}

We all know that clean, quiet, safe, comfortable, and healthy environments are an important component of successful learning (Schnider 2002:1). The unlimited enrolment of students at HBUs places a tremendous pressure on physical facilities. Students find themselves standing or sometimes being outside of the class because there is no ample space. The capacity of student enrolments has doubled but they buildings are still the same. All these impact on teaching and learning as well as the academic outcome.

Nokomo (1990) attributed the poor education of Blacks to the following: "The accession of National Party to power brought about a qualitative change in every aspect of life. In the education domain, segregated and inferior schooling was legislated for Africans in 1953, Coloureds in 1963 and Indians in 1965, providing an ideological cornerstone for social segregation, economic exploitation and political oppression of these groups, calibrated according to their location on the racially hierarchical social system. Education historically served as an instrument to ensure white domination over all Blacks. Blacks attended poorly constructed and overcrowded school facilities resulting in poor instruction and performance." According to the National Education, Health and Allied Workers Union (Nehawu) in the SAHRC report (2014:21)“...Historically white institutions still have an exaggerated concentration of resources for infrastructural development to the peril of historically black universities " and that this infrastructural disadvantage continues to hamper transformation and achievement of equity."

What Nkomo highlighted happened long time ago and unfortunately even today not much has been changed. So we could conclude that "School facilities affect learning, Spatial Configurations, noise, heat, light, and air quality obviously bear on students' and teachers' ability to perform (Schneider 2002:16). Infrastructural challenges continue to affect not only the academic outcome but also the institutional operations of the HBUs.

\section{Adequate Funding}

According to Steyn et al (2014:4) "the main concern of many university students around the world is related to finances. University studies are generally expensive as they involve the acquisition of study materials, participation in student activities and procurement of accommodation." What further compounded funding problems was the ever-increasing enrolment of students at this time. After the democratic elections, more people saw a future in tertiary education and this led to the overstretching of resources that were limited from the onset (Leshoro: 2008:25)

Today many historically black universities are in dire straits as a result of financial constrains ( Kunie 2001:162). Kingdon and Knight (2001:1) in Manala (2010: 524) confirm that South Africa has remarkably high unemployment rate. According to Letseka and Maile (2008:5) "since 1994 there has been increased migration of the black middle class from previously disadvantaged black townships to previously privileged whitesonly suburbs, and their children now attend the privileged former white schools. But in comparison to this relatively small 
proportion of the Black population, vast numbers of Black Africans remain trapped in poverty in townships and rural areas. The majority of their parents and guardians are poorly educated, and in the worst cases not educated."

Paraphrasing Cornwell and De Beer (2008:36) the unemployment rate as well as the enormous increase in pupil numbers has financial implications because the costs of formal education are extremely high. What we need therefore in this regard is what Badat (2010:16) proposes: "an enabling policy framework that encompasses thoughtful state supervision, effective steering, predictability, continuity and consistency in policy for higher education to realize its social purpose and goals. Such a framework must also be supported and reinforced by adequate state funding, otherwise the promise of higher education will be undermined by financial constrains." The causal relationship between finances and academic success cannot be underestimated (Steyn et al 2014: 5). Du Plessis (2000:67) quoting (cf RSA,1995; Collins,2000:2) sees the unattainability of the ideal equality in South Africa being the following two reasons:

- The first being the economic reality that the state does not have the financial means to bring about the necessary changes to the public education sector. According to Duplessis an investigation by by Collins comes to the conclusion that education should be seen as "an investment by taxpayers in a process vital to economic growth, job creation and social peace." Duplessis further argues that Government's "prime education aim has been to strive for what it calls 'equity and redress', not efficiency in serving the economy."

- The second reason is the threat of political domination of educational reform. What Collins call the "ideological sinkhole." This has led to what Collins calls "counter-productive ideological intervention." Individual and educational interests are overshadowed by politically inspired ideological motives.

\section{Curriculum}

The principal task of students is to acquire knowledge as well as the capacity to generate new knowledge (Mbeki 2010:15). The former President Mbeki further emphasizes that "that process must, of necessity expose them to the world of ideas and therefore the habit of critical enquiry. It would enable them to question the present and develop their own vision about the future."

Unfortunately in the words of Rooy et al (2000:54) the previous educational systems in South Africa denied many people access to opportunities to gain the information, skills and experience necessary to develop the people of this country ad to make the economy grow. These systems were content based and did not promote the idea that people should think analytically, or be critical and creative. Learners were not encouraged to come up with new ideas and take control of their learning situations and their lives. This problem is still persisting even up to today if not rife.

\section{E. Graduation Rates and Unemployment}

The relevant question as far as the above is that, are we training students for unemployment or for absorption of South
African economy? According to Letseka and Maile (2008: 2) "Higher education institutions produce an insufficient number of graduates, particularly black graduates. Some studies argue that universities are not producing enough graduates with relevant qualifications for the labour market. Others point out that the labour market has discrimination problems for its own, most conspicuous in a deliberate refusal to employ graduates from historically black universities."

Higher education must cultivate the knowledge, competencies and skills that enable graduates to contribute to economic development, since such development can facilitate initiatives geared towards social equality and social equality and social development. In many cases there is also a need for extensive restructuring of qualifications and programmes to make curricula more congruent with the knowledge knowledge, expertise and skills needs of a changing economy" (Badat 2010:14).

\section{F. Teaching and Learning Versus Research and Publication}

Matos (2000: 17) stresses that the main functions of university education are the development of high-level human capacity, the advancement and application of new kmowledge, and the generation and transmission of ideology, with the concomitant provision of intellectual leadership.

Being a good educator demands much more than just knowledge and the ability to communicate it. Today's educators must keep on studying in order to stay on top of developments, and to be able to apply their teaching to the latest insights about how people learn, Nieman et al (2005: 1).

Higher education is very competitive in South Africa. Some institutions are not burdened with large numbers of students and therefore resourced to engage in research and knowledge generation. Whereas in HBUs the focus is only on teaching and learning.

The other objective of funding higher education should be that of trying to help produce indigenous researchers rather than importing outside researchers ( Leshoro 2008:26). Matos (2000:16) and I agree with him when he says, "Today, a growing number of students from affluent households and ruling political classes opt to study overseas and that government and other institutions, rather than giving priority to local professionals, prefer the services of foreign experts to carryout studies and consultancies.

The campaign to isolate the HBUs in earlier times has ensured that progressive academics did not take up appointments there (Reddy 1992:60). Teaching and learning should be parallel with research and publication. For the above to run smoothly within a given institution lecturers must undertake their tasks accordingly. Crous et al (2000:12) highlights the task of the lecturer through the following basic functions that shows how comprehensive this job is:

- Discovering and generating new knowledge through research and other academic activities.

- Accumulating and storing knowledge in books, libraries, museums, computers and so forth.

- Disseminating accumulated knowledge through teaching, publications, films videos, the Internet and external professional activities. 
- Realizing educational aims and objectives through the teaching of his or her subject so that students' thinking, attitudes and dispositions are moulded by the meaningful learning that occurs.

All these factors contribute to disadvantaging seriously the historically Black universities. To limit their role even further, by denying to them, a legitimate role as research centres will be to deliver a serious blow to their development and transformation (Reddy 1992:60).

Lecturers are not only supposed to engage in teaching and learning but they must be scholars, researchers and lifelong learners too. But sometimes with the unbearable workload some even fail to improve their mere qualifications.

According to Crous et al (2000:12) good teaching does not however depend only on lecturer's ability to transmit information. Their personal characteristics also play a major role.

The quality of education of a nation could be determined by the quality of her teachers as well as characteristics such as certification status and degree in area of specialization which are very significant and positively correlated with students learning outcomes (Abe 2014:10). At the centre of higher education activity is therefore the development of minds and the transmission of skills and the challenge is to stimulate further development of inquisitive minds, to help students to develop their capacity to understand natural and social phenomena (Matos 2000:16).

\section{RELEVANCE AND QUALITY}

According to Steyn (2000) quality education and equality in education is, understandably, a major concern in South Africa, especially within the context of the educational transformation to a democratic lifestyle. Brand (2000:81) argues that the whole issue is complex and may even be characterized as a dilemma. Quality and standards are difficult to define in as much as the meanings sometimes overlap but are different. "A standard is usually a measurable outcome indicator. It refers to a specific level of quality, skill, ability or achievement by which someone or something is judged and considered to be necessary or acceptable."

Steyn (2000:22) asserts that quality education is a buzzword not only in commerce and industry but it has also become part of our educational context. Steyn further states that we may for example, distinguish between quality as:

- Excellence.

- Perfection.

- Fitness for more.

- Value for money and,

- Transformation.

In the latter meaning quality of education should be firstly linked to the improvement and development of process of change. In other words enhancing transformation processes (Steyn 2000:22).

The HBUs needs to ask themselves the following question: What does quality mean in the context of education? Financial shortcomings and derived consequences in the operation of higher education institutions lead to the unquestioned conclusion that the quality of education and research (and, as a consequence, the quality of graduates) has deteriorated (Matos 2000:16). Many definitions of quality in education exists, testifying to the complexity and multifaceted nature of the concept. The terms efficiency, effectiveness, equity and quality have been used synonymously (Adams, 1993). According to the UNICEF report (2000:4) quality education includes the following:

- Learners who are healthy, well-nourished and ready to participate and learn, and supported in learning by their families and communities;

- Environments that are healthy, safe, protective and gender-sensitive, and provide adequate resources and facilities.

- Content that is reflected in relevant curricula and materials for the acquisition of basic skills.

- Knowledge in such areas as gender, health, nutrition, and HIV/AIDS prevention and peace.

- Processes through which trained teachers use child-centred teaching approaches in well managed classrooms and schools and skillful assessment to facilitate learning and reduce disparities.

- Outcomes that encompass knowledge, skills and attitudes, and are linked to national goals for education and positive participation in society.

"Quality education should bring about positive changes; outcomes that fit with the goals valued by those participating in the educational process" (Van Zyl), 1992) in (Steyn 2000). According to de Klerk (2000:40) quality is the texture of something. A school, for instance, must be measured against certain criteria. The values undergirding quality are, among others, excellence, diligence, punctuality, self-control, independence, critical thinking, creativity and discipline. To borrow from Matos, lack of relevance, internal problems as well as survival strategies are issues that delay among others the HBUs to respond adequately to the demands posed the element of quality in higher education.

\section{IMPLIMENTATION}

Transformation is not only paramount for education's own sake but also because education is recognized as crucial for transforming other spheres of social life (Pendlebury 1998:334). Transformation is not restricted to apparent or physical transformation but also includes cognitive transcendence (Harvey and Knight 1996:7). Harvey and Knight are also correct in saying, "education is a participative process. Students are not products, customers, consumers, service users or clients- they are participants. The essence of transformation must surely be the effective and equitable distribution of the benefits of higher education across the population (Scott 2017:26)." I believe that HBUs can play a critical role by becoming agents of change in the context of transformation. Therefore the HBUs in dealing with the highlighted challenges as well as fostering desired change should adhere to the following:

1) Get adequate funding, competent design, construction and maintenance of infrastructure.

2) Allow competent leadership to emerge instead of 'inbreeding' and following the legacy of the patriarchal 
structures inherited from the former regime.

3) Engaging in a vision for a sociocultural and curricular revamping so that the educational system is not geared towards reproducing cultural distortions and economic disparities.

4) As the number of students increase there must be also a number of new staff members appointed to help with the influx.

5) Deal with Corruption decisively.

6) Deal with institutional quality constraints.

7) Weed out those who are retarding the process.

8) Promote values that are resourceful for education research, development, teaching and learning, innovation and community engagement.

9) To challenge the over-reliance of the academy on the dominant. Euro-American epistemologies, as the sole benchmarks of excellence while negating the importance of drawing from other knowledge systems often relegated as unscientific and unsystematic.

10) To give students adequate knowledge of their history, beliefs and culture so that they may participate fully in the life of the community.

11) To build up our student's sense of self esteem.

12) To develop character in our students.

13) To develop a sense of belonging to our students so that they may participate actively in community and societal affairs.

14) Reinforcing the relationship between teaching and research.

15) Encouraging ongoing professional development among lecturers.

\section{CONCLUSION}

Though there are notable changes within the higher education context not much has been done so far. Vilakazi and Tema (1991:127) assretted that "Black students in white universities will suffer from a high failure rate." That has been proven a number of times. So while Students are psychlogicaly compelled to prove themselves in historically white universities the other challenge is that if they studied from historically black institutions they don't get employed.

In the words of Kunnie (2000:172) "post- apartheid South Africa is at a cross road as far as educational and social transformation is concerned. Therefore it is imperative that all persons committed to the empowerment of the oppressed and disposed through education, especially formal educators and educational policy-makers realize the need for the adoption of and praxis of a qualitatively different socio-educational system."

In order to focus on a way forward the following questions by (Steyn et al 2014:6) needs to be asked by HBUs:

- What are the university's assumptions about its own reputation and the students it wants to recruit?

- Does the university have concerns about the financial and academic resources needed to provide support for Black students to be successful?

- What support services are available to students who have difficulty with English?

\section{REFERENCES}

[1] Abe, T.O. “ The Effect of Teachers Qualifications on Students Performance in Mathematics. Sky Journal of Educational Research, vol. 2, no. 1, pp. 10-14. 2014.

[2] Badat, S. "The Challenges of Transformation in Higher Education \& Training Institutions in South Africa. April, 2010.

[3] Brand, H. "Quality indicators for South African Schools against the background of International practices. Presented at the Democratic Transformation of Education in South Africa Conference, Stellenbosch, pp.79-87, 2000.

[4] CHE Report, " South African Higher Education in the Decate of Democracy," pp. 1-325, November, 2004.

[5] Cornwell, L \& De Beer, F. " Development Problems and Institutions," Pretoria: University of Pretoria.

[6] Crous, S.F.M. et al, The adult as Learner. Pretoria: University of South Africa.2000.

[7] Danner, H. "Phenomenology and Educational Discourse," Heinman Philosophy of Education Series, pp.1-9. 1997.

[8] Department of Education, Education White Paper 5 on Early Childhood Education: Meeting the challenges of early childhood development in South Africa. Pretoria: Department of Education. 2001, pp.4.

[9] De Klerk, J. "The Values Underlying Quality and equality in Educational Transformation," Presented at the Democratic Transformation of Education in South Africa Conference. Stellenbosch, pp. 36-44, 2000.

[10] Du Plessis, W. "Official Policy Related to Quality and Equality in Education: A Documentary Study," Presented at the Democratic Transformation of Education in South Africa Conference, Stellenbosch, pp 62-69.2000

[11] Du Toit, P.J "Revisiting The Foundations of Education in Africa," $1^{\text {st }}$ ed. South Africa: Hebron Press, 2007,ch.2, pp14-21.

[12] Elias, J.L. " A History of Christian Education. Protestant, Catholic, and Orthodox Pespectives," Malabar, Florida: Krieger Publishing Company, 2002.

[13] Esterhuyse, W. “ Truth as a Trigger for Transformation: from Apartheid injustice to Transformational Justice. In looking Back, Reaching Forward: Reflections on the Truth and Reconciliation Commission of South Africa, 2000. Zed Books.

[14] G. Gbadamosi \& J De Jager. "What you see is what you get": service quality, students' perceptions and satisfaction and South African Universities. South African Journal of Higher Education, 2009. 23: 877-893. https://doi.org/10.4314/sajhe.v23i5.48806

[15] Harvy,L \& Knight, P.T. “ Transforming Higher Education,” The Society for Research into Higher Education, Buckingham: Open University Press.

[16] Hoppers, C.O. “ Adding New Voices to the Higher Education Script," In Leadership,pp. 42-45.

[17] Kaya, H.O. " Black and White Universities in South Africa: The Challenge of Change," Indentity, Culture \& Politics, vol.1,no1. pp.89 $-100$

[18] Kunnie, J. "Indigenous African Philosophies and Socio-educational Transformation in 'Post- apartheid Azania'," in African Voices in Education. Juta \& Co.LtD. 2000. pp. 158- 178.

[19] Letseka, M 7 Maile, S. " High University Dropout Rates: A Threat to South Africans Future," HSRC Report, pp.1-12. March, 2008

[20] Lodge, T. "The Final Transition," The Indicator South Africa, vol.11,no 3. Winter

[21] Leshoro, T.M. “ The Financial Crisis at Historically Black Universities in South Africa: An Analysis of Policy Debates With Special Reference to the University of the Western Cape," M. Admin. Thesis, University of Western Cape, South Africa, 2008.

[22] Manala, M.J. 'A Better Life for All': A Reality or Pipe-Dream? A Black Theology Intervention in Conditions of Poor service Delivery in the Democratic South Africa, Scriptura, vol. 105, pp. 519-531, 2010 https://doi.org/10.7833/105-0-170.

[23] Matos, N. " The Nature of Learning, Teaching and Research in Higher Education in Africa. In African Voices in Education. 2000. pp12-38.

[24] Mbeki,T. Setting Free Intellectual Potential of Africa. In Leadership, pp.15-17.2010.

[25] Nieman, M.M. et al. " The Educator as Mediator of Learning," Pretoria: University of South Africa. 
[26] Nkomo, M. “ The Pedagogy of Dominion. Trenton, New Jersey: Africa World Press.1990.

[27] Reagan, T. Non- Western Educational Traditions. Indigenous approaches to Educational Thought and Practice. Mahwah, New Jersey: Lawrence Erlbaum Associates, 2005.

[28] Reddy, J. "Research and The Role of The Historically- Black Universities," Transformation, 18, 1992, pp. 58-65.

[29] SAHRC Report, "Transformation at Public Universities in South Africa," 2014. pp .88.

[30] Schneider, M. " Do School Facilities Affect Academic Outcomes?" pp.1-24. November, 2002.

[31] Steyn, J. " Balancing Quality and Equality in Educational Transformation," Presented at Stellenbosch, pp.21-27. 2000.

[32] Steyn, M.G, Harris, T. \& Hartell, C.G. "Institutional Factors That Affect Students' Perceptions of Early Childhood Teacher Education," South African Journal of Education, vol 34., no. 3, pp.1-7, August 2014. https://doi.org/10.15700/201409161107

[33] The World Book Encyclopedia. USA: World Book, 1988.

[34] UNICEF Report, “ Defining Quality Education," Presented at the International Working Group on Education, Italy, June 2000.

[35] Van Rooy, T, Claassen, C \& Schulze, S. "Teaching, Learning \& Development in Adult Education," 2000, Pretoria: University of South Africa.

[36] Van Zyl, C. "What is Quality Education? Pretoria: HSRC Conference. 1992.

[37] Vilakazi, H. \& Tema B, “White Universities and the Black Revolution in South Africa: Inside the White Power Structure. In Knowledge and Power in South Africa. Braamfontein: Skotaville Publishers. 1991.

[38] W. Fraser \& R. Killen, "The perceptions of students and lecturers of some factors influencing academic influence at two South African Universities," Perspective in Education, 2005, 23,pp 25-40. www.dictionary.com. Accessed on Thursday $26^{\text {th }}$ October 2017. 